\title{
Prevalence of Helicobacter pylori, gastric atrophy and intestinal metaplasia in gastric biopsy specimens: A retrospective evaluation of 1605 patients
}

\author{
Mehmet Ali Kosekli \\ Department of Gastroenterology, Bolu Abant Izzet Baysal University, Faculty of Medicine, Bolu, Turkey
}

\begin{abstract}
Aim: To evaluate the prevalence of Helicobacter pylori (H. pylori) and related histopathological lesions in gastric mucosa samples in this single-center study.

Methods: Esophagogastroduodenoscopy and endoscopic biopsy reports of 1605 elective cases were retrospectively evaluated. Histopathological examination was evaluated according to the Sydney classification. The data were analyzed according to the prevalence of H. pylori, age, gender, gastric atrophy and intestinal metaplasia rates, and the distribution of the study group in the population below 40 years old and over 40 years old.

Results: 584 males (Mean age $51.5 \pm 16.5$ years) and 1021 females (mean age $49.6 \pm 16$ years), $(p=0.03$ ), a total of 1605 cases were included in the study. The rate of atrophy, metaplasia and $\mathrm{H}$. pylori positivity in total study population were $0.2 \%, 16 \%, 71 \%$, respectively. The rate of atrophy in men and women were $1.2 \%$ and $0.8 \%$, respectively $(p=0.006)$. The rate of metaplasia in men and women were $20.9 \%$ and $13.7 \%$, respectively $(p<0.001)$. In the population under 40 years of age, the rates of gastric atrophy and intestinal metaplasia were $0.7 \%$ and $2.5 \%$, respectively $(p=0.02)$, above the age of 40 , these rates were determined as $10.8 \%$ and $18.4 \%$, respectively. ( $p<0.001)$.
\end{abstract}

Conclusion: According to the data of our center, the prevalence of $H$. pylori is high. In addition, the rate of intestinal metaplasia is relatively high in the male population over the age of 40 .

Key words: Helicobacter pylori, Helicobacter infections, gastric atrophy, intestinal metaplasia.

$\triangle$ Dr. Mehmet Ali Kosekli

Department of Gastroenterology, Bolu Abant Izzet Baysal University, Faculty of Medicine, Bolu, Turkey

E-mail: kosekli@gmail.com

Received: 2021-06-14 / Revisions: 2021-07-03

Accepted: 2021-07-06 / Published online: 2021-10-01

\section{Introduction}

Helicobacter pylori (H. pylori) is a common infection that infects nearly half of the world's population [1]. After ingestion orally, H. pylori is colonized in the gastric mucosa by creating a micro-alkaline environment thanks to its urease enzyme. It causes damage to the gastric epithelium with the endotoxins it secretes [2]. If it is not eradicated, it may cause many different pictures in a wide spectrum ranging from chronic gastritis to mucosa-related lymphoma and gastric cancer [3].

World health organization acknowledged it as the first-degree agent responsible for malignancy and the detection of a reduction in the risk of gastric cancer with its eradication keep the subject up-to-date [4-6]. While the prevalence of $H$. pylori decreases in parallel with the development level of the society and good sanitation conditions, it has been reported that low socio-economic status, dense family population and poor hygiene conditions are responsible for the increase in its prevalence [7]. 
There are different data from different geographical regions of our country about the prevalence of $H$. pylori [8]. The aim of this study was to evaluate the prevalence of Helicobacter pylori, atrophic gastritis and intestinal metaplasia in biopsy samples of 1605 patients who underwent esophagogastroduodenoscopy (EGD) in a referral hospital, and to investigate its relationship with gender and age.

\section{Materials and methods}

Approval of the study was obtained from Pamukkale University clinical research ethics committee (24.03.2021-2021 / E.35738). Data of 1605 adult cases who applied to Denizli State Hospital Gastroenterology Outpatient Clinic and underwent elective EGD with different indications between October 2015 and May 2016 were retrospectively evaluated. Pentax EPK i-5000 system and EG-2990i model gastroscope were used in EGD procedures. Patients who had gastrointestinal bleeding in the last month, who used antibiotics and bismuth salts, who used proton pump inhibitors in the last two weeks, and those who could not give a clear anamnesis about drug use and whose medical records could not be reached were excluded [9]. In addition, patients who underwent gastric surgery, inpatients, and emergency procedures were excluded. Endoscopic biopsy specimens taken from the two curvatures of the corpus and antrum were transported to pathology in formaldehyde containing tubes, stained with giemsa and toluidine blue, and histopathological examination was evaluated according to the Sydney classification[10]. The prevalence of $H$. pylori in the EGD treated population, its distribution by age and gender, rates of gastric atrophy and intestinal metaplasia, as well as the distribution of the study group in the group under 40 years of age and in the population over 40 years of age were analyzed.

SPSS (Statistical Package for Social Sciences) for Windows 16.0 program was used for the statistical analysis of the findings obtained in the study. Values greater than $\mathrm{P}<0.05$ were considered significant. The normality of data distribution was checked with the KolmogorovSmirnov test. T-test was used for statistics of normally distributed data, and Mann-Whitney $\mathrm{U}$ test was used to compare data that did not conform to normal distribution. Categorical data were compared using the Chi-square test. The Pearson correlation test was used for the correlation of the data with normal distribution, and the Spearman correlation test was used for the correlation of the data that did not fit the normal distribution.

\section{Results}

Total study population was consisted of 1605 subjects (584 men and 1021 women) enrolled to the study. The rate of gastric atrophy, intestinal metaplasia and $H$. pylori positivity in total study population were $0.2 \%, 16 \%, 71 \%$, respectively.

Mean age of the men was $51.5 \pm 16.5$ years, while mean age of the women was $49.6 \pm 16$ years, respectively $(p=0.03)$. The rate of gastric atrophy in men and women were $1.2 \%$ and $0.8 \%$, respectively $(p=0.006)$. The rate of intestinal metaplasia in men and women were $20.9 \%$ and $13.7 \%$, respectively ( $p<0.001)$. The rate of $H$. pylori positivity in men and women were $72.1 \%$ and $71.5 \%$, respectively $(p=0.8)$.

We grouped study population according to the age either as younger than 40 years (group I) or 40 years or older (group II). There were 153 (35.2\%) men and $282(64.8 \%)$ women in younger than 40 years group while 431 (36.8\%) men and $739(63.2 \%)$ women in 40 years and older group $(p=0.54)$. The rate of gastric 
Table 1. Distribution of $H$. pylori and associated lesions in study groups.

\begin{tabular}{|l|l|l|l|l|l|l|}
\hline Parameters & Female & Male & Total & $<$ 40 years & $>$ 40 years & $\boldsymbol{P}$ \\
\hline H. pylori (+) & $730(71.5 \%)$ & $421(72.1 \%)$ & $1151(71.7 \%)$ & $316(72.6 \%)$ & $835(71.4 \%)$ & NS \\
\hline H. pylori (-) & $291(27.9 \%)$ & $163(28.5 \%)$ & $454(28.3 \%)$ & $119(27.4 \%)$ & $335(28.6 \%)$ & NS \\
\hline Gas. Atr. (+) & $13(1.3 \%)$ & $19(3.3 \%)$ & $32(2 \%)$ & $3(0.7 \%)$ & $29(2.5 \%)$ & 0.01 \\
\hline Int. Met (+) & $140(13.7 \%)$ & $122(20.9 \%)$ & $262(16.3 \%)$ & $47(10.8 \%)$ & $215(18.4 \%)$ & $<0.001$ \\
\hline
\end{tabular}

Gas. Atr: Gastric atrophy, Int. Metap: Intestinal metaplasia, NS: Non-significant.

atrophy in groups I and II were $0.7 \%$ and $2.5 \%$, respectively $(p=0.02)$. The rate of intestinal metaplasia in groups I and II were $10.8 \%$ and $18.4 \%$, respectively $(p<0.001)$. The rate of $H$. pylori positivity in groups I and II were $72.6 \%$ and $71.4 \%$, respectively $(p=0.61)$. Distribution of $H$. pylori and associated lesions in study groups is summarized in Table 1.

\section{Discussion}

The frequency of $H$. pylori, gastric atrophy and intestinal metaplasia in the study population is $71 \%, 0.2 \%, 16 \%$, respectively. While there was no significant difference in the prevalence of $H$. pylori in the population aged younger than 40 and 40 or over, gastric atrophy and intestinal metaplasia are significantly higher than the younger group $2.5 \%, 18.4 \%$, respectively.

Biopsy samples taken from the antrum and corpus walls during EGD performed for various indications, especially dyspeptic complaints, provide valuable information about the gastric mucosa and enable us to detect the presence of H. pylori [11, 12]. According to the Sydney classification, histopathological changes in the gastric mucosa guide the clinician about potential precancerous lesions [10]. In the Kyoto classification, endoscopic findings associated with $H$. pylori gastritis and the endoscopic scoring system are recommended to be used to predict the risk of gastric cancer [13]. The sensitivity and specificity of the histopathological method in detecting $H$. pylori is high [14]. Patch colonization of $H$. pylori in the gastric lumen is a disadvantage of biopsy. Despite the high feasibility of urea breathe test in community screenings, its cost poses a significant disadvantage. In our study, only one method (histopathology) was used to detect $H$. pylori. In a study based on the urea breath test conducted throughout Turkey by dividing it into five sub-regions, the prevalence of $H$. pylori was found to be $65.7 \%$ in the Aegean region where our center is located, while this rate was relatively high in present study [8]. In this study, there was no data that samples were taken from our city, and there may be a difference depending on the method used in the detection of $H$. pylori. In the reflux study conducted by S. Bor et al. [15] from our region, the prevalence of $H$. pylori was $75.7 \%$. In another study reported from Afyon province, $H$. pylori prevalence was found to be $73 \%$ and $85 \%$ positive in PCR and antral biopsy results in dyspeptic patients [16]. Serological positivity of $H$. pylori was reported as $79.7 \%$ in 2001 from the same province [17]. H. pylori positivity was found to be $41.4 \%$ according to the results of CLO test performed on 9239 patients in Istanbul [18]. H. pylori positivity was found to be $57 \%$ and it was reported that there was no difference between the two methods in a study comparing urea breath test and histopathology [19]. H. pylori was found to be $40 \%$ and intestinal metaplasia was found to be $18.1 \%$ as reported in a study conducted in 
Konya in 2014 [20]. In a series of 885 cases covering 0-17 years of age, the prevalence of $H$. pylori was found to be $47.2 \%$ [21]. Our findings were similar to the literature.

Chronic inflammation and destructions in the gastric mucosa that last for years result in gastric atrophy and metaplasia if $H$. pylori infection initiated in childhood is not eradicated, [3, 22]. The contribution of $H$. pylori to non-cardia gastric cancer is reported to be $74.7 \%$ [23] . The rates of gastric atrophy and intestinal metaplasia found in our study in the group above 40 years of age were $2.5 \%$ and $18 \%$, respectively which were similar when compared to the results of other centers. Intestinal metaplasia rate was reported as $11.5 \%$ from Bursa, while gastric atrophy rate was $16.3 \%$ and intestinal metaplasia rate was $13.5 \%$ in Thrace region $[24,25]$. In two different studies presented from Istanbul, the prevalence of intestinal metaplasia was reported as $13.4 \%$ and $17.8 \%$ [26, 27]. Intestinal metaplasia occurs as a result of cells migrating from the small or large intestines to the stomach as substitution of the damaged gastric mucosa. Intestinal metaplasia, which is an important step on the way to gastric dysplasia, was found to be significantly higher in the male population above 40 years of age in present report. Undoubtedly, many factors other than $H$. pylori contribute to the development of gastric adenocarcinoma, such as genetic, environmental factors and eating habits [28-30]. Therefore, high H. pylori positivity does not always mean a high prevalence of gastric cancer.

This cross-sectional study, which was retrospective in design, based on a single center and a single method, has no claim other than leading large-scale research to be conducted under ideal conditions. Another limitation of the study is that intestinal metaplasia subgroups were not reported in histopathological examinations.

\section{Conclusion}

This cross-sectional study, based on data from a single-center referral hospital, showed that the prevalence of $H$. pylori is still high and that the prevalence of gastric atrophy and intestinal metaplasia is similar to data reported in the literature. In addition, gastric atrophy and intestinal metaplasia were found to be significantly higher in the group over 40 years of age. Moreover, multi-centered and ideally up-to-date studies are needed on this subject.

Funding: The author(s) received no financial support for the research, authorship, and/or publication of this article.

Conflict of Interest: The authors declare that they have no conflict of interest.

\section{Ethical statement:}

The study was approved by Local Clinical Research Ethics Committee (Date and Decision Number: 24.03.2021-2021 / E.35738), and written informed consent was obtained from each subject.

\section{Open Access Statement}

This is an open access journal which means that all content is freely available without charge to the user or his/her institution under the terms of the Creative Commons Attribution NonCommercial License (http://creativecommons.org/licenses/bync/4.0). Users are allowed to read, download, copy, distribute, print, search, or link to the full texts of the articles, without asking prior permission from the publisher or the author.

Copyright (c) 2021: Author (s).

\section{References}

[1]Brown LM. Helicobacter pylori: epidemiology and routes of transmission. Epidemiologic reviews. 2000;22(2):283-97. 
[2]Jankowski J. Helicobacter pylori infection and gastric cancer. BMJ: British Medical Journal. 1991;302(6791):1534.

[3]Correa P. Human gastric carcinogenesis: a multistep and multifactorial process-first American Cancer Society award lecture on cancer epidemiology and prevention. Cancer research. 1992;52(24):6735-40.

[4]Cancer IAfRo. Schistosomes, liver flukes and Helicobacter pylori: IARC Lyon; 1994.

[5]Lee Y-C, Chiang T-H, Chou C-K, et al. Association between Helicobacter pylori eradication and gastric cancer incidence: a systematic review and meta-analysis. Gastroenterology. 2016;150(5):1113-24. e5. [6]Kishikawa H, Ojiro K, Nakamura K, et al. Previous Helicobacter pylori infectioninduced atrophic gastritis: A distinct disease entity in an understudied population without a history of eradication. Helicobacter. 2020;25(1):e12669.

[7]Vaira D, Vakil N. Blood, urine, stool, breath, money, andHelicobacter pylori. Gut. 2001;48(3):287-9.

[8]Ozaydin N, Turkyilmaz SA, Cali S. Prevalence and risk factors of helicobacter pylori in Turkey: a nationallyrepresentative, cross-sectional, screening with the $13 \mathrm{C}$-Urea breath test. BMC Public Health. 2013;13(1):1-12.

[9]Malfertheiner P, Megraud F, O'morain C, et al. Management of Helicobacter pylori infection - the Maastricht V/Florence consensus report. Gut. 2017;66(1):6-30.

[10] Stolte M, Meining A. The updated Sydney system: classification and grading of gastritis as the basis of diagnosis and treatment. Canadian journal of gastroenterology. 2001;15(9):591-8.

[11]Lee JH, Park YS, Choi KS, et al. Optimal Biopsy Site for $\mathrm{H}$ elicobacter pylori Detection during Endoscopic Mucosectomy in Patients with Extensive Gastric Atrophy. Helicobacter. 2012;17(6):405-10.

[12]Lan H-C, Chen T-S, Li AF-Y, et al. Additional corpus biopsy enhances the detection of Helicobacter pylori infection in a background of gastritis with atrophy. BMC gastroenterology. 2012;12(1):1-10.

[13] Toyoshima O, Nishizawa T, Koike K. Endoscopic Kyoto classification of Helicobacter pylori infection and gastric cancer risk diagnosis. World journal of gastroenterology. 2020;26(5):466.

[14]Best LM, Takwoingi Y, Siddique S, et al. Non-invasive diagnostic tests for Helicobacter pylori infection. Cochrane Database of Systematic Reviews. 2018(3).

[15]Bor S, Kitapcioglu G, Kasap E. Prevalence of gastroesophageal reflux disease in a country with a high occurrence of Helicobacter pylori. World journal of gastroenterology. 2017;23(3):525.

[16] Altındiş S, Altındiş M, Özdemir M, et al. Dispeptik yakınmalı hastaların dental plak ve mide biyopsi örneklerinde helicobacter pylori'nin real time-PCR ile araştırılması. SDÜ Tıp Fakültesi Dergisi. 2010;17(2):1-7.

[17] Altındis M. Afyon bölgesinde Helicobacter pylori enfeksiyon sıklığı. Genel Tıp Dergisi. 2001;11(3):109-13.

[18]Sar1 YS, Sander E, Erkan E, et al. Endoscopic diagnoses and CLO test results in 9239 cases, prevalence of Helicobacter pylori in Istanbul, Turkey. Journal of gastroenterology and hepatology. 2007;22(11):1706-11.

[19]Korkut Y, Kilit T, Işık İ, et al. Dispepsi şikâyeti ile başvuran hastalarda helikobakter pilori pozitifliği açısından C-14 üre nefes testi ile endoskopinin karşılaştırılması. Family Practice and Palliative Care. 2016;1(1):9-12. 
[20] Korkmaz H, Kerpic O, Temel T. Konya Bölgesinde Gastroskopi Yapılan Hastalarda Histopatolojik Bulgular ve Helicobacter Pylori Sıklığı. Osmangazi Tıp Dergisi. 2014;36(1):44-9.

[21] Gurbuz BC, Inceman HN, Aydemir M, et al. Prevalence of Helicobacter pylori among children in a training and research hospital clinic in Istanbul and comparison with Updated Sydney Classification Criteria. Northern Clinics of İstanbul. 2020;7(5):499. [22]Björkholm B, Falk P, Engstrand L, et al. Helicobacter pylori: resurrection of the cancer link. Journal of internal medicine. 2003;253(2):102-19.

[23] Axon A. Helicobacter pylori and public health. Helicobacter. 2014;19:68-73.

[24] Mete R, Oran M, Güneş H, et al. Tekirdağ bölgesinde Helicobacter pylori prevalansı ve patolojik parametrelerin çok yönlü analizi; literatür ile güncelleme. Genel Tıp Derg. 2014;24:1-6.

[25] Adim Şb, Filiz G, Gürel S, et al. Kronik Gastrit Olgularında İntestinal Metaplazi Sıklığı ve İntestinal Metaplazi İle Helicobacter Pylori İlişkisi. Uludağ Üniversitesi Tıp Fakültesi Dergisi.34(1):1-4. [26] Emre E, Ahishali E, Dolapçioğlu C, et al. Peptik Ülser ve Gastrit Saptanan Hastalarda Helicobacter Pylori Sıklığı. Journal of Kartal Training \& Research Hospital/Kartal Egitim ve Arastirma Hastanesi Tip Dergisi. 2013;24(2).

[27] Ozdil K, Sahin A, Kahraman R, et al. Current prevalence of intestinal metaplasia and Helicobacter pylori infection in dyspeptic adult patients from Turkey. Hepato-gastroenterology. 2010;57(104):1563-6.

[28] Sakamoto H, Yoshimura K, Saeki N, et al. Genetic variation in PSCA is associated with susceptibility to diffuse-type gastric cancer. Nature genetics. 2008;40(6).

[29] Tanikawa C, Urabe Y, Matsuo K, et al. A genome-wide association study identifies two susceptibility loci for duodenal ulcer in the Japanese population. Nature genetics. 2012;44(4):430.

[30] Kono S, Hirohata T. Nutrition and stomach cancer. Cancer Causes \& Control. 1996;7(1):41-55. 